\title{
Dental Caries Prevalence and Severity among Deaf and Hearing Impaired Male Students in Eastern Saudi Arabia
}

Yazeed Al-Qahtani ${ }^{1}$, Hashim Al-Naser ${ }^{2 *}$, Dhya Al-Nahawi ${ }^{2}$, Fawaz Al-Tuwaijri ${ }^{3}$, Mujtaba Al-Abdullati ${ }^{\text {2 }}$, Thikriat Al-Jewair ${ }^{4}$

${ }^{1}$ Security Forces Hospital, Ministry of Interior, Saudi Arabia

${ }^{2}$ Ministry of Health, Saudi Arabia

${ }^{3}$ Dental Interns, University of Dammam, Saudi Arabia

${ }^{4}$ State University of New York at Buffalo, USA

Submission: June 23, 2017; Published: July 12, 2017

*Corresponding author: Hashim Al-Naser, General Dental Practitioner, Ministry of Health, Saudi Arabia, P0 box 2613, Alhasa 7546-36345, Saudi Arabia, Email: alnaser.hashim@gmail.com

Abstract Arabia.

Objectives: To assess dental caries prevalence and severity in hearing-impaired (HI) and deaf adolescent male students in Eastern Saudi

Materials and methods: A cross-sectional study was conducted of 109 male students (46 HI and 63 deaf) between the ages 12 -18 yrs. The students were compared with 218 control students with no hearing disabilities. Two trained examiners carried out clinical examinations to assess the prevalence of dental caries using the Decayed, Missing, Filled surfaces (DMF/S) index. Data were analyzed by age category (12-14yrs, $>14-16 y r s$, and $>16-18 y r s$ ) and by hearing disability. The DMF/S index was dichotomized at the 75 th percentile to determine the severity of dental caries.

Results: More than two-thirds of the students had "Decayed" surfaces. The differences were statistically significant (P=0.003) between the $\mathrm{HI}$ and control groups for those 12-14 yrs of age. Twelve percent of the whole sample was caries free and $22 \%$ had severe dental caries (mean $\mathrm{DMF} / \mathrm{S}>13)$.

Conclusion: Dental caries was more prevalent in the deaf and HI groups compared to the controls. Severe dental caries was more common in the deaf than in the HI. Public health efforts are needed to address the high caries prevalence.

Keywords: Dental caries; Epidemiology; Hearing loss; Deafness

\section{Introduction}

Dental caries is the localized destruction of susceptible dental hard tissues by acidic by-products from bacterial fermentation of dietary carbohydrates [1]. This occurs when the cariogenic microorganisms produce enzymes that decrease the $\mathrm{pH}$ levels below 5.5, resulting in demineralization of enamel and breakdown of hard tooth structure.

The risks of dental caries include poor oral hygiene, plaque accumulation, sugary diet, low income and education, in addition to other factors $[2,3]$. According to the World Health organization (WHO), in the year 2000, $68 \%$ of adults in 184 countries had less than 3 Decayed, Missed, and Filled teeth (DMFT) [4]. In Saudi Arabia, the prevalence of dental caries was $95 \%$ in the primary dentition with a mean DMFT of $7.34[5,6]$ and around $91 \%$ in the permanent dentition with a mean DMF score of $7.35[6,7]$.
Normal hearing is the ability to recognize, interoperate, and respond to the verbal, or noise stimuli by humans or animals capable of producing sounds. The term "hearing impairment" and "hearing loss" indicate that the audiometry is below the threshold for normal hearing, which is around $15 \mathrm{~dB}$. In cases of severe or complete loss of hearing, the term "deaf" is described. This disability can either be inherited, or acquired through time, or disease.

In developed countries, hearing impairment (HI) is considered the most common birth defect and sensorineural disorder [8]. Over 360 million people are generally affected by this disorder, 32 million $(9 \%)$ of them are children. South Asian countries have the highest prevalence of hearing loss (27\%), while Middle Eastern countries having the lowest (3\%) [9]. Hearing loss is more common in males (56\%) than in females (44\%) [9]. 
Children with hearing disabilities experience difficulty in communicating with their oral health providers. Even more critical, not all dentists are able to treat children with special needs. This is partly due to the lack of education in dental schools on dealing with special needs groups, as well as the limited number of training programs on special needs patient [10]. Several studies have shown that children with hearing disabilities have poor oral hygiene and high levels of dental caries and periodontal disease $[10,11]$.

Only one study assessed the dental caries prevalence among special needs children in Saudi Arabia [12]. Assessed the prevalence of dental caries in deaf, blind and mentally retarded female students in two age groups (6-7yrs, and 11-12yrs) in the city of Riyadh. The investigators reported greater caries prevalence in the special needs students than the normal controls with a DMFT of $(7.35,5.12),(6.58,3.89),(8.00,5.81)$ in the deaf, blind, and mentally retarded age groups, respectively.

Further studies are needed to determine the extent of dental caries in special needs groups in Saudi Arabia. The objective of this study was to assess and compare dental caries prevalence and severity in $\mathrm{HI}$ and deaf adolescent students attending governmental schools in the Eastern region of Saudi Arabia.

\section{Materials and Methods}

This cross-sectional study assessed one hundred and twentytwo deaf and HI male students attending governmental schools that apply the integrated learning program in the cities of Khobar, Dammam, and Qatif. These cities were chosen to represent all levels of socioeconomic status in the region. All schools that teach deaf and HI students in the cities were included $(\mathrm{N}=7)$. Four of the schools teach deaf students and the other three teach HI students.

The inclusion criteria were deaf and HI male students who have no other disabilities, age range from 12-18 years old, full permanent dentition excluding third molars, and native Saudi. Subjects were excluded if they had cognitive impairment, craniofacial anomalies, or if they refused to participate. The data were collected between January and March of 2015.

The cases were compared with a randomly selected sample of control students without hearing disabilities from the same schools at a ratio of 1:2 for a total of 218 male controls. Controls were matched to the cases by age and gender. The study was approved by the Research and Ethics Committee of the Deanship of Scientific Research at the University of Dammam (IRB 2015-02-009).

Eligible students were invited to participate. Parental written consent and student verbal assent were both obtained. The parents were then asked to complete a 4-item questionnaire that included demographic information: marital status, father's and mother's educational level, socioeconomic status, and medical history. The WHO oral health questionnaire for children [13] was used to assess the perceived oral health status and behaviors in students. It is a 14-item questionnaire that elicits information about the following: Demographics (age, school level, and performance in school), perceived oral health status, oral health behaviors (i.e., brushing, flossing, use of toothpick), frequency of cariogenic food consumption, and adverse habits (i.e., smoking). Both students' and parents' questionnaires were translated into Arabic and were pilot tested on 17 students and 17 parents who were not part of the study before distribution and the items were modified accordingly.

Students then underwent intra-oral examinations to assess the prevalence and severity of dental caries on all permanent teeth surfaces using the DMF/S index. The DMF/S is composed of a "D" component for decayed, "M" component for missing, and " $F$ " component for filled teeth surfaces. Teeth surfaces covered with preventive sealants were considered sound. The examinations were conducted using a portable dental chair, disposal mirrors, explorers (kit No.99113), gauzes, and a light source. The WHO criteria were followed for the diagnosis of dental caries in the 140 surfaces of the 28 permanent teeth [13].

Data were collected by two examiners (Q.Y and N.H.) and recorded by two others (N.D. and T.F.). Prior to data collection, both examiners and recorders underwent a period of training and calibration on the use of the DMFT/DMFS indices against a senior faculty member. Five patients who were not part of the main study were examined. The inter-examiner reliability was measured using kappa statistic and the results ranged from 0.6 to 0.8 , which indicated substantial agreement. The examinations were also repeated within one week to assess intra-examiner repeatability, which was also high (0.7-0.8). All calibrations were repeated twice during the data collection period to ensure repeatability.

\section{Statistical analysis}

Descriptive statistics were firstly conducted for all variables using means standard deviations (SD), frequencies, and histograms. The outcome of interest was the DMF/S components. Bivariate analyses were conducted using Pearson's Chi-square test (Fisher's exact test when appropriate) for categorical variables and Analysis of Variance for continuous variables. Independent variables such as age were categorized into: $12-14 \mathrm{yrs},>14-16 \mathrm{yrs}$, and $>16-18 y$ rs. The monthly income variable was categorized into low, medium, and high income according to King Khalid Foundation's low-income cut-offs in Saudi Arabia <8,000 SR (equivalent to 2134 US dollars) [14] Differences in the mean $\mathrm{DMF} / \mathrm{S}$ between the three groups were analyzed using one-way Analysis of variance (ANOVA) followed by Tukey's Post-Hoc test to assess differences between groups. The DMF/S index was dichotomized into (DMFS $=0$, DMFS $>0$ ) to compare caries free with caries present. The same variable was also cut-off at the 75 th percentile to assess caries severity (DMF/S $\leq 13, \mathrm{DMF} / \mathrm{S}>13$ ). The percentage D, M, F surfaces were also calculated. The significance level was set at $5 \%$ using two tailed tests. Data were analyzed using SPSS version 22 for Windows. 


\section{Advances in Dentistry \& Oral Health}

\section{Results}

A total of 122 deaf and HI students were eligible. Thirteen students were excluded for different reasons (five were mentally retarded and eight were above 18 years of age). A total of 109 students were included, 46 of them were $\mathrm{HI}$ and 63 were deaf. Table 1 presents the demographic characteristics of the sample. More than $48 \%$ of the students were in the $>14-16$ age group.

Table 1: Demographic characteristics of the sample*.

\begin{tabular}{|c|c|c|}
\hline Variables & $\mathbf{N}$ & $\%$ \\
\hline \multicolumn{3}{|l|}{ Students } \\
\hline \multicolumn{3}{|l|}{ Group } \\
\hline Deaf & 63 & 19.7 \\
\hline $\mathrm{HI}$ & 46 & 14.1 \\
\hline Control & 218 & 66.7 \\
\hline \multicolumn{3}{|l|}{ Age } \\
\hline $12-14$ & 105 & 32.1 \\
\hline$>14-16$ & 158 & 48.4 \\
\hline$>16-18$ & 64 & 19.5 \\
\hline \multicolumn{3}{|l|}{ Parents } \\
\hline \multicolumn{3}{|l|}{ Marital status } \\
\hline Married & 264 & 98.5 \\
\hline Not-married & 4 & 1.5 \\
\hline \multicolumn{3}{|c|}{ Father's educational level } \\
\hline College or higher & 72 & 22.1 \\
\hline High school or less & 255 & 77.9 \\
\hline \multicolumn{3}{|c|}{ Mother's educational level } \\
\hline College or higher & 51 & 15.6 \\
\hline High school or less & 276 & 84.4 \\
\hline \multicolumn{3}{|l|}{ Monthly income } \\
\hline$>8000 \mathrm{SR}$ & 100 & 40.3 \\
\hline $8000-16000$ SR & 96 & 38.7 \\
\hline$<16000$ SR & 52 & 21 \\
\hline
\end{tabular}

Numbers do not add up due to missing data*

The majority of the parents had low educational level. Forty percent of the families were considered below the poverty line. Around $53.3 \%$ of the fathers and $41.2 \%$ of the mothers reported having diabetes.

Table 2 shows the dental history and habits of the students. Most students rated their oral health as good. The deaf students reported the least frequency of dental visits where $40 \%$ had never visited a dentist while only $14 \%$ visited that dentist more than once a year.

Table 3 presents the mean DMF/S for the three age and disability groups. The largest component of DMF/S was the "D" in all the groups. Post hoc analyses revealed significant differences in the " $\mathrm{D}$ " component and the "DMF/S" $(\mathrm{P}=0.005$ and $\mathrm{P}=0.003$, respectively) between the $\mathrm{HI}$ and control groups.
Table 2: Dental history and behaviors of the students.

\begin{tabular}{|c|c|c|c|c|c|c|c|}
\hline Group & Deaf & & HI & & Control & & $\mathbf{P}$ \\
\hline Variable & $\mathbf{N}$ & $\%$ & $\mathbf{N}$ & $\%$ & $\mathbf{N}$ & $\%$ & \\
\hline Age & & & & & & & $<0.001^{*}$ \\
\hline $12-14$ & 13 & 20.6 & 25 & 54.4 & 67 & 30.7 & \\
\hline$>14-16$ & 18 & 28.6 & 11 & 23.9 & 129 & 59.2 & \\
\hline$>16-18$ & 32 & 50.8 & 10 & 21.7 & 22 & 10.1 & \\
\hline $\begin{array}{l}\text { Oral health } \\
\text { self-rating }\end{array}$ & & & & & & & 0.815 \\
\hline Good & 29 & 65.9 & 21 & 56.8 & 110 & 61.8 & \\
\hline Fair & 6 & 13.6 & 9 & 24.3 & 35 & 19.7 & \\
\hline Poor & 9 & 20.5 & 7 & 18.9 & 33 & 18.5 & \\
\hline $\begin{array}{l}\text { Brushing } \\
\text { frequency }\end{array}$ & & & & & & & 0.357 \\
\hline $\begin{array}{c}\text { Twice a day or } \\
\text { more }\end{array}$ & 22 & 36.7 & 10 & 23.2 & 53 & 28.8 & \\
\hline Once a day & 18 & 30 & 20 & 66.5 & 55 & 29.9 & \\
\hline $\begin{array}{c}\text { Few times a } \\
\text { week }\end{array}$ & 14 & 23.3 & 10 & 23.3 & 58 & 31.5 & \\
\hline Never & 6 & 10 & 3 & 7 & 18 & 9.8 & \\
\hline $\begin{array}{l}\text { Use of } \\
\text { fluoridated } \\
\text { toothpaste }\end{array}$ & & & & & & & 0.088 \\
\hline Yes & 42 & 70 & 22 & 52.4 & 62 & 34.3 & \\
\hline No & 11 & 18.3 & 7 & 16.7 & 26 & 14.4 & \\
\hline Don't know & 7 & 11.7 & 13 & 31 & 93 & 51.4 & \\
\hline $\begin{array}{l}\text { Use of dental } \\
\text { floss }\end{array}$ & & & & & & & $0.004^{*}$ \\
\hline Yes & 5 & 12.2 & 1 & 5.9 & 40 & 33.3 & \\
\hline No & 36 & 87.8 & 16 & 94.1 & 80 & 66.7 & \\
\hline $\begin{array}{l}\text { Frequency of } \\
\text { dental visit }\end{array}$ & & & & & & & 0.357 \\
\hline $\begin{array}{c}\text { More than once } \\
\text { a year }\end{array}$ & 8 & 13.8 & 11 & 25.6 & 48 & 26.2 & \\
\hline Once a year & 10 & 17.2 & 9 & 20.9 & 26 & 14.2 & \\
\hline $\begin{array}{c}\text { Less than once } \\
\text { a year }\end{array}$ & 17 & 29.3 & 12 & 27.9 & 58 & 31.7 & \\
\hline Never & 23 & 39.7 & 11 & 25.6 & 51 & 27.9 & \\
\hline Smoking & & & & & & & 0.487 \\
\hline Yes & 3 & 7.9 & 1 & 2.9 & 16 & 9 & \\
\hline No & 35 & 92.1 & 33 & 97.1 & 161 & 91 & \\
\hline $\begin{array}{l}\text { Frequency } \\
\text { of cariogenic } \\
\text { foods }\end{array}$ & & & & & & & 0.058 \\
\hline $\begin{array}{c}\text { Less than once } \\
\text { a day }\end{array}$ & 29 & 27.5 & 19 & 52.8 & 82 & 48.5 & \\
\hline Once a day & 8 & 20 & 8 & 22.2 & 41 & 24.3 & \\
\hline $\begin{array}{c}\text { Few times a } \\
\text { day }\end{array}$ & 3 & 7.5 & 9 & 25 & 46 & 27.2 & \\
\hline $\begin{array}{l}\text { Frequency } \\
\text { of cariogenic } \\
\text { beverages }\end{array}$ & & & & & & & 0.495 \\
\hline
\end{tabular}




\begin{tabular}{|c|c|c|c|c|c|c|c|}
\hline $\begin{array}{c}\text { Less than once } \\
\text { a day }\end{array}$ & 27 & 64.3 & 22 & 62.9 & 92 & 51.7 & \\
\hline Once a day & 9 & 21.4 & 9 & 25.7 & 53 & 29.8 & \\
\hline $\begin{array}{c}\text { Few times a } \\
\text { day }\end{array}$ & 6 & 14.3 & 4 & 11.4 & 33 & 18.5 & \\
\hline
\end{tabular}

Significant at the 0.05 level *
The percentage decayed, missing, and filled surfaces by age and disability are presented in Figure 1. More than $97 \%$ of the deaf and $81.8 \%$ of the $\mathrm{HI}$ in the $12-14$ age group had decay compared to $64.9 \%$ in the controls, (ANOVA, $\mathrm{P}=0.009$ ). The differences between the $\mathrm{HI}$ and controls were statistically significant (Tukey's test, $\mathrm{P}=0.005$ ).

Table 3: Mean DMFS by age group and disability.

\begin{tabular}{|c|c|c|c|c|c|c|c|c|c|c|c|c|c|c|c|}
\hline \multirow[t]{2}{*}{ Variable } & \multicolumn{4}{|c|}{$12-14$} & \multicolumn{5}{|c|}{$>14-16$} & \multicolumn{6}{|c|}{$>16-18$} \\
\hline & Deaf & HI & Control & Total & & Deaf & HI & Control & Total & & Deaf & HI & Control & Total & \\
\hline & $\begin{array}{c}\text { Mean } \\
\text { (SD) }\end{array}$ & $\begin{array}{c}\text { Mean } \\
\text { (SD) }\end{array}$ & $\begin{array}{l}\text { Mean } \\
\text { (SD) }\end{array}$ & $\begin{array}{c}\text { Mean } \\
\text { (SD) }\end{array}$ & $\mathbf{P}$ & $\begin{array}{c}\text { Mean } \\
\text { (SD) }\end{array}$ & $\begin{array}{c}\text { Mean } \\
\text { (SD) }\end{array}$ & $\begin{array}{c}\text { Mean } \\
\text { (SD) }\end{array}$ & $\begin{array}{c}\text { Mean } \\
\text { (SD) }\end{array}$ & $\mathbf{P}$ & $\begin{array}{c}\text { Mean } \\
\text { (SD) }\end{array}$ & $\begin{array}{c}\text { Mean } \\
\text { (SD) }\end{array}$ & $\begin{array}{c}\text { Mean } \\
\text { (SD) }\end{array}$ & $\begin{array}{c}\text { Mean } \\
\text { (SD) }\end{array}$ & $\mathbf{P}$ \\
\hline \multirow[t]{2}{*}{ DS } & 8.6 & 10.3 & 5.2 & 6.8 & 0.004 & 9.3 & 4.3 & 4.2 & 6.4 & 0.073 & 9.6 & 12 & 10.2 & 10.2 & 0.813 \\
\hline & 7.5 & 9 & 5.4 & 7 & & 8.3 & 2.8 & 6.2 & 6.4 & & 9.5 & 10.5 & 11.7 & 10.3 & \\
\hline \multirow[t]{2}{*}{ MS } & 0.4 & 2.6 & 0.4 & 0.9 & 0.116 & 0 & 0.9 & 0.2 & 0.2 & 0.109 & 1.6 & 1.5 & 1.1 & 1.4 & 0.877 \\
\hline & 1.4 & 9.2 & 1.8 & 4.8 & & 0 & 3 & 1 & 1.2 & & 3.2 & 3.4 & 2.6 & 3 & \\
\hline \multirow[t]{2}{*}{ FS } & 0 & 1.2 & 0.8 & 0.8 & 0.105 & 0.9 & 2.4 & 1 & 1.1 & 0.169 & 2.8 & 0.8 & 1.9 & 2.2 & 0.329 \\
\hline & 0 & 2.1 & 1.7 & 4.8 & & 1.6 & 4.6 & 2.1 & 2.3 & & 5.5 & 1.9 & 2.7 & 4.3 & \\
\hline \multirow[t]{2}{*}{$\mathrm{DMF} / \mathrm{S}$} & 9 & 14.2 & 6.4 & 8.6 & 0.004 & 10.2 & 7.5 & 7.4 & 7.7 & 0.318 & 14 & 14.3 & 13.2 & 13.8 & 0.96 \\
\hline & 7.8 & 16.5 & 6.2 & 10.2 & & 8.5 & 7.5 & 7.2 & 7.4 & & 11.2 & 12.8 & 12.7 & 11.8 & \\
\hline
\end{tabular}

Significance level is $0.05^{*}$

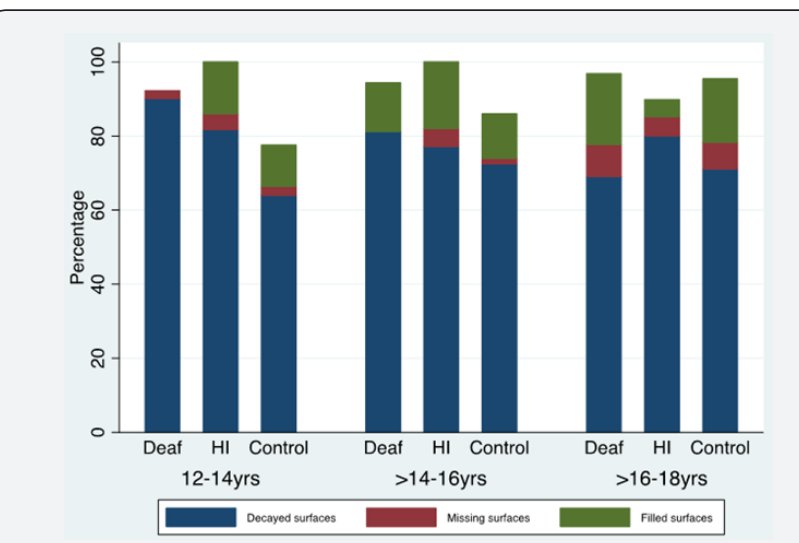

Figure 1: Percentage decayed, missing and filled surfaces in Deaf, $\mathrm{HI}$, and control groups.

Table 4: Percentage students with caries in the groups.

\begin{tabular}{|c|c|c|c|c|c|c|c|}
\hline & \multicolumn{2}{|c|}{ DMF/S=0 } & \multicolumn{2}{c|}{ DMF/S $<0$} & OR & $\mathbf{9 5 \% ~ C I ~}$ & P \\
\hline Variable & $\mathbf{N}$ & $\mathbf{\%}$ & $\mathbf{N}$ & $\mathbf{9}$ & & & \\
\hline Control & 34 & 15.6 & 184 & 84.4 & - & - & - \\
\hline Deaf & 3 & 4.8 & 60 & 95.2 & 3.7 & $\begin{array}{c}1.1- \\
12.5\end{array}$ & 0.035 \\
\hline HI & 1 & 2.2 & 45 & 97.8 & 8.3 & $\begin{array}{c}1.1- \\
62.4\end{array}$ & 0.039 \\
\hline Total & 38 & 11.6 & 289 & 88.4 & & & \\
\hline
\end{tabular}

OR=Odds Ratio; $\mathrm{Cl}=$ Confidence Interval
Only $11.7 \%$ of the total sample was caries free, Table $4 . \mathrm{HI}$ students had eight times higher odds of dental caries compared to control students $(\mathrm{OR}=8.3,95 \%$ Confidence interval [CI] 1.1-62.4, $\mathrm{P}=0.039$ ). Severe forms of dental caries ( $\mathrm{DMF} / \mathrm{S}>13$ ) were present in $22.3 \%$ of the sample, $34.9 \%$ of those affected by severe caries were in the deaf group, Table 5.

Table 5: Percentage students with severe DMF/S.

\begin{tabular}{|c|c|c|c|c|c|c|c|}
\hline & \multicolumn{2}{|c|}{ DMF/S $\leq 13$} & \multicolumn{2}{|c|}{ DMF/S >13 } & OR & 95\% CI & P \\
\hline Variable & $\mathbf{N}$ & $\%$ & $\mathbf{N}$ & $\mathbf{\%}$ & & & \\
\hline Control & 181 & 83 & 37 & 17 & - & - & - \\
\hline Deaf & 41 & 65.1 & 22 & 34.9 & 2.6 & $1.4-4.9$ & 0.003 \\
\hline HI & 32 & 69.6 & 14 & 30.4 & 2.1 & $1.0-4.4$ & 0.039 \\
\hline Total & 254 & 77.7 & 73 & 22.3 & & & \\
\hline
\end{tabular}

\section{OR=Odds Ratio; $\mathrm{Cl}=$ Confidence Interval}

\section{Discussion}

This is first study on caries experience and oral hygiene practices among HI and deaf male adolescents in the Eastern province of Saudi Arabia. 
The main finding of the study was the high prevalence of caries in adolescents with hearing disabilities. The prevalence of caries was affected by age, where the older age groups had more permanent teeth decayed and higher prevalence of dental caries.

The overall mean DMF/S for all participants in this study was 10.03. This is greater than the findings of (Jain et al. 2008) who demonstrated a dental caries prevalence of $36.8 \%$ with a mean $\mathrm{DMF} / \mathrm{S}$ of 3.7 among Indian special needs children between the ages 5 and 22 years. It is also slightly higher than the prevalence (mean DMF/S=8.7) reported for disabled children and young Kuwaiti adults (Shyama et al. 2001). The differences between our study and the two previous studies could be due to the low education level and low awareness of dental hygiene in our sample. The sample in our study was also more homogenous than the previous studies that included subjects in different age groups.

The differences between the controls and the HI students in the 12-14 years age group were statistically significant for the " $D$ " component and the $\mathrm{DMF} / \mathrm{S}(\mathrm{P}=0.005$ and $\mathrm{P}=0.003$, respectively). The difference was also significant for the " $F$ " component for the same disability and age groups (P-value of 0.003 ). These findings are clinically significant and highlight the needs of students with hearing impairment for dental care.

In the present study, Only $11.6 \%$ of the sample was caries free compared to $24.2 \%$ in a previous study (Shyama et al. 2001). The differences in the caries burden between our study and the other study can partly be explained by the different age, gender, and type of disability examined. Our study excluded adolescents with mental retardation compared to the earlier study.

The deaf group had the most severe dental caries among the three groups. Almost $40 \%$ of the deaf students reported never visiting a dentist before. Also, $10 \%$ of them do not brush and $88 \%$ do not floss. Those factors may explain the high DMF/S in the deaf group in comparison to the rest of the sample.

The DMF/S increased with age in the deaf, HI and control groups. This finding is consistent with earlier studies [12,15-17] as a result of the accumulation of carious lesions and the chronic nature of dental caries.

The present study provided baseline descriptive data for future comparisons. Since dental caries is a preventable disease, it is hoped that these results would help in the planning of dental prevention and restorative services targeting this group.

This study however had some limitations. It was not possible to include female participants in the study due to cultural and logistic limitations. A similar study on females is important to study gender differences. The sample in this study was over represented by low-income families. The results cannot be generalized to subjects in other income levels or in different regions. Future studies are warranted to examine the burden of caries in subjects with other disabilities. A study with larger sample size and longterm follow-up is also recommended.

\section{Conclusion}

Dental caries was more prevalent in the deaf and HI groups compared to the controls. More severe forms of the disease were more common in the deaf (34.9\%) than in the HI (30.4) and controls (16.8\%). The prevalence of dental caries increased with age in all the groups. Public health efforts are needed to address the high caries prevalence.

\section{Conflict of Interest}

The authors declare no conflict of interest.

\section{Funding}

This research did not receive any specific grant from funding agencies in the public, commercial, or not-for-profit sectors.

\section{References}

1. Selwitz RH, Ismail AI, Pitts NB (2007) Dental caries. Lancet 369(9555): 51-59.

2. Struzycka I (2014) The oral microbiome in dental caries. Pol J Microbiol 63(2): 127-135.

3. Saldūnaitė $K$, Bendoraitienė EA, Slabšinskienė E, Vasiliauskienė I, Andruškevičienè V (2014) The role of parental education and socioeconomic status in dental caries prevention among Lithuanian children. Medicina 50(3): 156-161.

4. Petersen PE, Bourgeois D, Bratthall D, Ogawa H (2005) Oral health information systems--towards measuring progress in oral health promotion and disease prevention. Bull World Health Organ 83(9): 686-693.

5. Al-Wazzan KA (2004) Dental caries prevalence in 6-7 year-old schoolchildren in Riyadh region: A comparative study with the 1987 oral health Survey of Saudi Arabia Phase I. Saudi Dent J 16: 54-60.

6. Al-Ansari A (2014) Prevalence, severity, and secular trends of dental caries among various saudi populations: A literature review. Saudi Med Medicinal Sci 2(3): 142-150.

7. AlDosari AM, Wyne AH, Akpata ES, Khan NB (2003) Caries prevalence among secondary school children in Riyadh and Qaseem. Saudi Dent J 15: 96-99.

8. Pagon RA, Adam MP, Ardinger HH, et al. (1993-2015) GeneReviews $®$. University of Washington, Seattle, USA.

9. World Health Organization (2012) WHO global estimates on prevalence of hearing loss Hearing loss estimates. WHO, Switzerland, Geneva.

10. Krause M, Vainio L, Zwetchkenbaum S, Inglehart MR (2010) Dental education about patients with special needs: a survey of U.S. and Canadian dental schools. J Dent Edu 74(11): 1179-1189.

11. Shyama M, Al-Mutawa SA, Morris RE, Sugathan T, Honkala E (2001) Dental caries experience of disabled children and young adults in Kuwait. Community Dent Health 18(3): 181-186.

12. Al-Qahtani Z, Wyne AH (2004) Caries experience and oral hygiene status of blind, deaf and mentally retarded female children in Riyadh, Saudi Arabia. Odontostomatol Trop 27(105): 37-40.

13. World Health Organization (2013) Oral health surveys: basic methods - 5th edition. WHO, Switzerland, Geneva.

14. King Khalid Foundation (2014) Low income cut offs. Riyadh, Saudi Arabia.

15. Jain M, Mathur A, Kumar S, Dagli RJ, Duraiswamy P, et al. (2008) Dentition status and treatment needs among children with impaired 
hearing attending a special school for the deaf and mute in Udaipur India. J Oral Sci 50(2): 161-165

16. Bernabé E, Sheiham A (2014) Extent of differences in dental caries in permanent teeth between childhood and adulthood in 26 countries. Int Dent J 64(5): 241-245.

This work is licensed under Creative Commons Attribution 4.0 Licens

DOI: 10.19080/ADOH.2017.07.555658
17. Bernabe E, Sheiham A (2014) Age, period and cohort trends in caries of permanent teeth in four developed countries. Am J Public Health 104(7): e115-21.

\section{Your next submission with Juniper Publishers will reach you the below assets}

- Quality Editorial service

- Swift Peer Review

- Reprints availability

- E-prints Service

- Manuscript Podcast for convenient understanding

- Global attainment for your research

- Manuscript accessibility in different formats

( Pdf, E-pub, Full Text, Audio)

- Unceasing customer service

Track the below URL for one-step submission https://juniperpublishers.com/online-submission.php 